\title{
Toward a taxonomy of architectural robotics
}

\author{
> Mahesh Daas \\ Ball State University, USA \\ mahesh@mahesh.org
}

\begin{abstract}
Robotics in architecture is a fast-emerging area of research and design today. The current research and practices of robotics in architecture tend to be, to a great degree, techno-positivist and framed by a narrowly defined instrumentalist view. The paper presents comprehensive taxonomy of a broad range of robotic applications so as to meaningfully guide, systematize, and clarify multi-faceted design or research explorations in architecture and beyond. The paper advances four frameworks: role of robotics in architecture; modes of interaction between robots, humans and architecture; the Vitruvian framework; and robots classified by form; all of which point to new avenues of potential exploration while also revealing the gaps and biases in the current research and design in the discipline.
\end{abstract}

Keywords: Robots; Architectural Robotics; Taxonomies; Robotic Fabrication

\section{Introduction}

Robotics in architecture is a fast-emerging area of research and design today (Braumann \& Brell-Cokcan, 2011; Braumann \& Brell-Cokcan, 2012; Brayer, 2013; Dierichs, Schwinn, \& Menges, 2013; Gramazio \& Kohler, 2014; Gramazio \& Kohler, 2014). Much of the discourse about robotics in architecture flows from the discourses about digital fabrication that impacted architecture in the past decade. There is a preoccupation with fabrication capacity of robots in most of the recent explorations. One technology figures greatly in the current discourses: articulated arm industrial robots that are mostly utilized on the assembly lines of advanced manufacturing industries.

The current research and practices of robotics in architecture tend to be, to a great degree, techno-positivist and framed by a narrowly defined instrumentalist view (Lavallee, Vroman, \& Keshet, 2011; Stavric \& Kaftan, 2012). Such approaches lack critical and humanistic reflection necessary to properly contextualize the new technologies within architecture and human societies. Such approaches also lack understanding of broader research possibilities, markets and societal needs that are absolutely necessary to innovate beyond merely one-off inventions or bespoke applications.

There is a need for comprehensive taxonomy of a broad range of robotic applications so as to meaningfully guide, systematize, reflect and clarify multi-faceted design or research explorations in architecture by learning from the taxonomic systems from other fields, and discuss their applicability to architecture.
Research in the fields of computer science, sociology and engineering has delved deeply into human-robot interaction (HRI) taxonomies, and advanced multiple frameworks of HRI that are transferable to architecture, but do not fit architecture (De Santis, Siciliano, De Luca, \& Bicchi, 2008; Yanco \& Drury, 2002). There is a paucity of scholarship in comprehensively addressing how architecture could be affected by a broad range of robotic technologies. The paper aims to address the gaps and deficiencies in the current discourses about robotics in architecture.

The paper advances four frameworks, which help classify and categorize different ways of approaching and evaluating robots and robotics in the context of architecture. The first framework examines the role of robotics in architecture; the second framework considers robotics through the modes of their interaction; the third framework applies a two-thousand year old framework of Vitruvian Triad; and the fourth framework classifies robots by their form to reveal the phenomenological and experiential aspect of robotics in architecture.

\section{Role of Robots in Architecture}

What role do robots and robotics play in architecture? A classification of the role of robots in architecture (see Framework 1) is useful to systematically understand the gamut of possibilities of how robotic technologies could inform, aid, transform and even become architecture.

So far, a lion's share of literature in the field is dedicated to 1.B, which addresses the role of robots in the bespoke fabrications 
or mass-customized manufacturing of architectural artifacts. Much of the current work is driven by the "how to" methodologies and technical or machine craft-based experiments, which characterize a research area that is its infancy.

Framework 1 suggests that robotics have a role to play throughout the design, building, operation and construction process. In frames 1.A through 1.C, the assumption is that robots are objects or systems that are distinctive from buildings and architecture. Additional assumption is that robots play an instrumental role, a mediating role and a utilitarian role in the process of design or construction of buildings.

\section{Framework 1: Role of robotics in the architectural design process}

\begin{tabular}{|c|c|c|c|}
\hline $\begin{array}{l}\text { A. Robots for } \\
\text { design }\end{array}$ & $\begin{array}{l}\text { B. Robots for } \\
\text { fabrication }\end{array}$ & \begin{tabular}{|l|} 
C. Robots for \\
operation
\end{tabular} & $\begin{array}{l}\text { D. Robots as } \\
\text { buildings }\end{array}$ \\
\hline $\begin{array}{l}\text { Desktop or } \\
\text { industrial robots } \\
\text { used in the } \\
\text { design process, } \\
\text { to inform the } \\
\text { design process } \\
\text { and prototyping }\end{array}$ & \begin{tabular}{|l|} 
Industrial robots \\
used for bespoke or \\
mass-customized \\
manufacturing or \\
deployed for in-situ \\
or off-site construc- \\
tion processes
\end{tabular} & $\begin{array}{l}\text { Autonomous } \\
\text { or semi-auton- } \\
\text { omous robotic } \\
\text { assemblies such } \\
\text { as building } \\
\text { skins, and other } \\
\text { components }\end{array}$ & $\begin{array}{l}\text { Dwelling in a } \\
\text { robot with ex- } \\
\text { tensive mobility, } \\
\text { autonomous or } \\
\text { semi-autono- } \\
\text { mous agencies }\end{array}$ \\
\hline
\end{tabular}

While frames 1.A through 1.C focus on robots and robotics in architecture, frame 1.D suggests that the separation or distinction between robots and architecture could be inverted or blurred where the buildings become robots for living in. Although Peter Cook and other utopian visionaries dreamed of gigantic cities that would wander the landscape, it is only now that we have the technological capacity to realize such visions (Silver, 2013). In such a world, just as we already have buildings or vehicles or crafts that are essentially computers, we could imagine and produce buildings and cities that are robots. Such robotic structures for living could open new avenues for smarter and greener living.

Further design explorations, speculations and research could take place in all categories of robotics in architecture understood through the role of robots.

After considering the role of robots and robotics, I propose four kinds of relationships that involve robots, humans and architecture (see Framework 2) when we consider the dimension of interaction between distinctive systems such as robots, buildings and humans.

\section{Framework 2: Robot-human-architecture interactions}

\begin{tabular}{|c|c|c|c|}
\hline $\begin{array}{l}\text { A. Architec- } \\
\text { ture }\end{array}$ & B. People & C. Robots & D. All \\
\hline $\begin{array}{l}\text { Robot-Archi- } \\
\text { tecture: } \\
\text { Robots } \\
\text { directly } \\
\text { engaging and } \\
\text { interacting } \\
\text { with buildings } \\
\text { or participate } \\
\text { in the design } \\
\text { and produc- } \\
\text { tion processes. }\end{array}$ & $\begin{array}{l}\text { Robot-Human: } \\
\text { Robots inter- } \\
\text { acting with } \\
\text { people in ar- } \\
\text { chitectural set- } \\
\text { tings, assisting, } \\
\text { augmenting, } \\
\text { and facilitating } \\
\text { usability. }\end{array}$ & $\begin{array}{l}\text { Robot-Robot: } \\
\text { Robots autono- } \\
\text { mously interacting } \\
\text { with other robots in } \\
\text { architectural settings. } \\
\text { Swarms of self-as- } \\
\text { sembling systems and } \\
\text { cellular automata. }\end{array}$ & $\begin{array}{l}\text { Robot-Hu- } \\
\text { man-Architec- } \\
\text { ture: } \\
\text { Three-way inter- } \\
\text { actions involving } \\
\text { robots, people } \\
\text { and buildings. } \\
\text { Essential frame } \\
\text { to consider for } \\
\text { robotic build- } \\
\text { ings. }\end{array}$ \\
\hline
\end{tabular}

Research into architectural robotics is still quite nascent and does not yet embrace all possible interactions between the three aspects of robots, people and architecture. Most current research, with a few exceptions (Tibbits, 2011), is focused on frame 2.A or 2.B, where robots and architecture interact, often mediated by human agencies.

The key point of the interaction framework of robotics is that robots do not exist in isolation; rather, they are constantly in interaction with one or the other elements of the built environment that must be taken into account for a holistic approach to integrating robotics into architecture.

\section{Vitruvian Triad Framework for Robotics in Architecture}

Vitruvian framework of Utilitas, Firmitas, and Venustas has been a two-thousand year-old way to understand the role of robotics in architecture. Marcus Vitruvius Pollio, an architect and theorist of antiquity proposed a triadic framework that has informed the field of architecture for millennia (Vitruvius Pollio \& Morgan, 1960; 1914). Yet, the full potential of the Vitruvian framework for other and intersectional fields (such as the intersection between robotics and architecture) is awaiting realization.

Seen through the Vitruvian lens, it can be seen that most discourses about architectural robotics have been concerned with utilitas and firmitas.

Framework 3: Vitruvian Triad of Robotics in Architecture

\begin{tabular}{|l|l|l|}
\hline A. Utilitas & B. Firmitas & C. Venustas \\
\hline $\begin{array}{l}\text { Efficiency, Speed, } \\
\text { Precision, Functional- } \\
\text { ity, Capacity of robots } \\
\text { and robotic agencies }\end{array}$ & $\begin{array}{l}\text { Strength, Reliability, } \\
\text { Modularity, Adapt- } \\
\text { ability, Instructability } \\
\text { of robots and robotic } \\
\text { agencies }\end{array}$ & $\begin{array}{l}\text { Interactivity, Zoomor- } \\
\text { phism, Co-presence, } \\
\text { Psychodynamics, Beauty } \\
\text { of robots and robotic } \\
\text { agencies }\end{array}$ \\
\hline
\end{tabular}

One of the valuable contributions of Vitruvius has been the recognition that utility, firmness and aesthetics/experience are not problems that can be solved in isolation from each other. Rather, architecture must be considered simultaneously from the three perspectives. While utility and firmness are easily understood, venustas has been understood less so even within the field of architecture (McEwen, 2003). Simply put the complex concept of venustas translates to love, aesthetics, grace and charisma that unite the humans into a community. Venustas represents the phenomenological and experiential aspects of architecture.

The venustas of robots or robotics, and its relevance to architecture is the area that is the biggest gap in the field. How do robots transform the experience of architecture for specific human beings (see Framework 2)? How do people experience robots in their different roles in architecture (see Framework 1)? When does the distinction between the experience of buildings and experience of robots blur (see frame 2.D)? How do robots affect the form and morphogenesis of architecture? Could we identify buildings made by robots or are robots themselves? How about the experience of robots in buildings in 
which robots are the main or one of the major demographics at some point in the near future in settings such as nuclear reactors or disaster relief? Could there be such a thing as robot-centered architecture? These are the kinds of questions that the Vitruvian framework as well as the two other frameworks proposed in this paper raise.

\section{Robots Classified by their Form}

Robots come in many different forms. The form of a robot is often an integral part of its function and structure. Four broad categories of robots could be identified by virtue of their form.

Framework 4: Robots considered by form

\begin{tabular}{|l|l|l|l|}
\hline A. Biomorphic & B. Mechanomorphic & C. Polymorphic & D. Amorphic \\
\hline $\begin{array}{l}\text { Robots that re- } \\
\text { semble animals, } \\
\text { humans, insects } \\
\text { and other living } \\
\text { beings. }\end{array}$ & $\begin{array}{l}\text { Robots that resemble } \\
\text { machines or embody } \\
\text { mechanical charac- } \\
\text { teristics in their form }\end{array}$ & $\begin{array}{l}\text { Robots that } \\
\text { assume different } \\
\text { forms }\end{array}$ & $\begin{array}{l}\text { Robots with } \\
\text { no identifiable } \\
\text { form }\end{array}$ \\
\hline
\end{tabular}

Biomorphic robots take on the formal or structural characteristics of biological systems, predominantly zoomorphic forms. Mechanomorphic robots might resemble a host of machines such as vehicles. Polymorphic robots assume different forms, not unlike those depicted in the films such as Transformers (Bay, 2007). Amorphic robots are those that do not possess distinguishing formal characteristics, but become part of systems in an inconspicuous or invisible fashion.

Of these different forms, biomorphic robots (humanoids, insectoids, etc.) hold the potential to engage in emotional and empathetic relationships between robots and humans (Minsky, 1985; Minsky, 2006)(Lewis \& Arbib, 1999) by virtue of their form. Boston Dynamics' Cheetah, Honda's ASIMO, Sony's AIBO and $Q R I O$, Hiroshi Ishiguro's Otonaroids, and Aldebaran Robotics' Nao are all examples of biomorphic robots. A long list of biomorphic robots is featured in popular films and literature such as Bicentennial Man (Columbus, 1999), Star Wars (Lucas, 1977), and Iron Giant (Hughes \& Davidson, 1968).

Mechanomorphic robots are often used in instrumental fashion. CNC milling machines of various kinds, NASA's Opportunity rover, the fictional character R2D2 in Star Wars (Ibid),

Polymorphic robots may consist of reconfigurable elements that could self-assemble (Tibbits, 2011).

Amorphic robots could be found widely used in responsive environments where there is an overarching form into which (or into which) robotic capabilities are transparently integrated (P. Beesley, 2006; P. Beesley, Gorbet, Ohrstedt, \& Isaacs, 2010; Bullivant, 2006). In popular lore, Aurthur Clark's fictional character HAL 9000 is an example of an amorphic robot (Clarke, 1968).

Thus, the form of a robot is an important characteristic that cannot be ignored when examining the robot-human interaction.

\section{Conclusions}

The field of robotics is coming of age. Architecture is being impacted by the technological advances in many different ways. At the moment, much research in architecture is focused on robotic fabrication using industrial articulated arm robots. Much research in the field is based on atomistic speculation and bespoke fabrication. The purpose of this paper is to provide systems of classification, categorization and begin to develop taxonomies of robots and robotics in architecture so that a more systematic and holistic work could take place in addressing the multifarious aspects of possible research.

Considered from the perspectives of role, interaction and phenomenology, robotics in architecture presents a rich array of possibilities for designers, researchers and theorists in the field. Robots and robotics are more than another technology; they are a phenomenon that is bound to transform our experience of architecture and of ourselves.

The paper's undertaking is significant in developing frameworks for understanding, classifying and defining the role, attributes, and human-robot-architecture interrelationships. In doing so, the paper is, arguably, one of the first attempts to guide the emergent field of architectural robotics toward greater integration into the frameworks and practices in architecture. Such frameworks and classifications would lead to taxonomies of architectural robotics that could guide well-rounded research and design explorations.

\section{References}

Murphy, D., DeSanto, T., \& Bryce, I. (Producers), \& Bay, M. (Director). (2007). Transformers. [Motion Picture] United States: Dreamworks Pictures.

Beesley, P. (2006). Responsive architectures: subtle technologies 2006 Riverside Architectural Press.

Beesley, P., Gorbet, R., Ohrstedt, P., \& Isaacs, H. (2010). Hylozoic Ground: liminal responsive architecture (1st ed.). Cambridge, Ont.: Riverside Architectural Press.

Braumann, J., \& Brell-Cokcan, S. (2011). Parametric Robot Control: Integrated CAD/CAM for Architectural Design.

Braumann, J., \& Brell-Cokcan, S. (2012). Real-Time Robot Simulation and Control for Architectural Design. 30th eCAADe Conference, Prague,

Brayer, M. A. (2013). Flight Assembled Architecture: Gramazio I\& Kohler and Raffaello D’Andrea HYX.

Bullivant, L. (2006). Responsive environments: architecture, art and design. London; New York: V \& a; Distributed in North America by Harry N. Abrams, Inc.

Clarke, A. C. (1968). A space odyssey. New York, NY: New American Library, Inc,

Bicentennial Man. Columbus, C. (Director). (1999).[Motion Picture] United States: Buena Vista Pictures.

De Santis, A., Siciliano, B., De Luca, A., \& Bicchi, A. (2008). An atlas of physical human-robot interaction. Mechanism and Machine Theory, 43(3), 253-270.

Dierichs, K., Schwinn, T., \& Menges, A. (2013). Robotic Pouring of Aggregate Structures. Rob| Arch 2012 (pp. 196-205) Springer.

Gramazio, F., \& Kohler, M. (2014). Made by Robots: Challenging Architecture at the Large Scale AD Wiley. 
Hughes, T., \& Davidson, A. (1968). The Iron Giant: A Story in Five Nights A. Knopf.

Lavallee, J., Vroman, R., \& Keshet, Y. (2011). Automated Folding of Sheet Metal Components with a Six-axis Industrial Robot. Proceedings of ACADIA 11: Integration through Computation [Proceedings of the 31st Annual Conference of the Association for Computer Aided Design in Architecture (ACADIA)], pp. 144-151.

Lewis, M. A., \& Arbib, M. (1999). Introduction to the Special Issue on Biomorphic Robots. Autonomous Robots, 7(3), 207-209.

Kurtz, G. (Producer), \& Lucas, G. (Director). (1977). Star Wars. [Motion Picture] United States: 20th Century Fox.

McEwen, I. K. (2003). Vitruvius: writing the body of architecture. Cambridge, Mass.: MIT Press.

Minsky, M. L. (1985). Robotics (1st ed.). Garden City, N.Y.: Anchor Press/Doubleday.

Minsky, M. L. (2006). The emotion machine: commonsense thinking, artificial intelligence, and the future of the human mind. New York: Simon \& Schuster.
Silver, M. (2013). Off-road City. ACADIA 13: Adaptive Architecture [Proceedings of the 33rd Annual Conference of the Association for Computer Aided Design in Architecture (ACADIA), Cambridge, Ontario, Canada. pp. 445-446.

Stavric, M., \& Kaftan, M. (2012). Robotic fabrication of modular formwork for non-standard concrete structures. Proceedings of the eCAADe Conference,

Tibbits, S. (2011). A Model for Intelligence of Large-scale Self-assembly. ACADIA 11: Integration through Computation [Proceedings of the 31st Annual Conference of the Association for Computer Aided Design in Architecture (ACADIA)], Banff, Canada. pp. 342-349.

Vitruvius Pollio, \& Morgan, M. H. (1960; 1914). Vitruvius: the ten books on architecture [De architectura.]. New York: Dover Publications.

Yanco, H. A., \& Drury, J. L. (2002). A taxonomy for human-robot interaction. Proceedings of the AAAI Fall Symposium on Human-Robot Interaction, pp. 111-119. 